\title{
Serum Resistin Level as a Diagnostic Marker in Non-Alcoholic Steatohepatitis
}

\author{
Sameh M. Abdel Monem ${ }^{1}$, Talaat Fathy ${ }^{1}$, Sally M. Shalaby ${ }^{2}$ \\ and Essam A. Wahab ${ }^{3}$ \\ Tropical Medicine ${ }^{1}$, Biochemistry ${ }^{2}$ and Internal Medicine ${ }^{3}$ Departments, \\ Faculty of Medicine, Zagazig University, Egypt
}

Corresponding Author Sameh M. Abdel Monem

\section{Mobile:}

$+201000641647$

\section{E mail:}

drsameh154@yahoo.c om

Key words: Resistin; Steatohepatitis; NAFLD
Background and study aim: Nonalcoholic fatty liver disease (NAFLD) is a state defined by extreme fat accumulation in the form of triglycerides (steatosis) in the liver. A subgroup of NAFLD patients characterized by injury to the hepatocytes and inflammation in addition to excessive fat, the latter condition, nominated nonalcoholic steatohepatitis (NASH). The work aimed to evaluate the role of serum resistin level as a diagnostic marker in patients with non-alcoholic steatohepatitis who were admitted to the Tropical Medicine and Internal Medicine departments, Faculty of Medicine, Zagazig University (inpatient and outpatient).

Patients and Methods: This study was performed on 38 patients between April 2017 to May 2018. They were classified into two groups; control group included 19 non-obese apparently healthy individuals, 11 males and 8 females with average age of 43.2 year and average body mass index

\section{INTRODUCTION}

Fatty liver diseases (FLD) is abnormal accumulation of fat mainly triglycerides in the Hepatocytes. It is a reversible condition. It is considered as single diseases and had multiple causes including excess alcohol and obese individuals (with or without insulin resistance). There is a relationship between FLD and other diseases that influence fat metabolism [1].

Non-alcoholic fatty liver disease (NAFLD) is one of the reasons of a fatty liver, occurring when fat is deposited in the liver due to causes other than excessive alcohol use [2].

NAFLD is considered as a hepatic manifestation of metabolic disorder (MD), and patients with NAFLD often have one or more components of the of $23.46 \mathrm{Kg} / \mathrm{m}^{2}$ and patients group included 19 patients with NASH, 13 males and 6 females with average age of 44 year and average body mass index of $32.71 \mathrm{Kg} / \mathrm{m}^{2}$. They had bright fatty liver on ultrasonographic examination and raised ALT and AST and liver biopsy confirmed the diagnosis of NASH. Clinical assessment, laboratory evaluation, pelvi-abdominal ultrasound, and serum resistin were done for all participants.

Results: In this study: Cut off level of serum resistin was $>3.7 \mathrm{ng} / \mathrm{ml}$ and there was a significant difference as regard serum resistin in NASH group in comparison with control group.

Conclusion: Serum resistin level was significantly higher among NASH group in comparison to the control group. Serum resistin level may be a good diagnostic marker for patients with NASH.

MD such as obesity, dyslipidemia, hypertension, and raised fasting plasma glucose levels or overt type 2 diabetes mellitus (T2DM) [3].

NAFLD may present as simple hepatic steatosis or steatohepatitis in which there is damage of hepatocytes together with inflammatory process in the liver secondary to oxidative stress caused by excess fat accumulation. It may end in fibrosis and cirrhosis and almost identical to those of alcoholic liver diseases [4].

Obesity, hyperlipidemia and T2DM are existing together conditions that frequently associate non-alcoholic fatty liver disease. The prevalence of obesity in several patients with non-alcoholic fatty liver disease ranged between (30$100 \%$ ), the prevalence of $\mathrm{T} 2 \mathrm{DM}$ ranged 
between (10-75\%), and the prevalence of hyperlipidemia ranged between (20-90\%) [5].

Adipose tissue is considered as an endocrine organ. It has an important role in energy homeostasis. It is responsive to both central and peripheral metabolic signals and itself has the capability of releasing many proteins. These adipocyte-specific proteins which termed adipokines have a variety of local, peripheral and central effects [3]. Resistin is a polypeptide specifically secreted from adipocytes [6]. Obesity is associated with increasing serum resistin. Resistin increases blood glucose, insulin resistance and impairs hypoglycemic response to insulin infusions [7]. Resistin may have role in NAFLD and may linked to degree of liver inflammation and grade of fibrosis [3].

This work was aimed to evaluate the role of serum resistin level as a diagnostic marker in patients with non-alcoholic steatohepatitis who were admitted to the Tropical Medicine and Internal Medicine Departments Faculty of Medicine, Zagazig University (inpatients and outpatient).

\section{PATIENTS AND METHODS}

\section{Study design and settings}

The study was carried out in the Tropical Medicine, Internal Medicine and Medical Biochemistry departments, Faculty of Medicine, Zagazig University Hospitals during the period from April 2017 to May 2018. The study design is comparative case control study with sample size of 38 persons.

\section{Target population and sampling}

The participants in this study were classified into two groups; Control group which included 19 non- obese apparently healthy people: they were 11 males and 8 females with body mass index range from 20 to $25 \mathrm{Kg} / \mathrm{m}^{2}$, average body mass index of $23.46 \mathrm{Kg} / \mathrm{m}^{2}$ and average age of 43.2 year. Patient group which included 19 NASH patients: they were 13 males and 6 females with body mass index range from 30 to $35 \mathrm{Kg} / \mathrm{m}^{2}$, average body mass index of $32.71 \mathrm{Kg} / \mathrm{m}^{2}$ and average age of 44 year they had bright fatty liver on ultrasonographic examination with raised serum ALT \& AST level and liver biopsy findings that confirm the diagnosis of NASH.

\section{Inclusion and Exclusion criteria}

Patients with elevated liver enzymes and bright liver by ultrasonography were examined and investigated for selection of patients with non- alcoholic steatohepatitis which was proved by liver biopsy and healthy subjects of matched age and sex were included as a control group. While patients who had history of alcohol consumption, positive hepatitis $\mathrm{B}$ and $\mathrm{C}$ virus markers, history of statin drug intake and any other metabolic or autoimmune liver diseases were excluded.

\section{Methods and study tools:}

Control and patient groups were subjected to:

- Full history taking with stress on persistent fatigue, malaise or right upper quadrant pain, dietary history and regimens for energy restriction, history of use of drugs especially lipid-lowering medications or anti diabetic drugs, history of alcohol consumption, family history of liver disease and metabolic hereditary and autoimmune causes. In addition to the history of surgical operation such as gastric or jejunoileal bypass.

- Thorough physical examination with focus on blood pressure, pulse, face complexion, hand and lower limb examination, Estimation of weight, height and calculation of body mass index, in addition to full detailed abdominal examination.

- Laboratory investigations included:

\section{Blood sample collection}

An 8-mL blood sample was taken from all participants after the subject rested at least 15 minutes between 8 and 9 a.m. after fasting period of 12-14 hours. The blood sample was divided into 2 portions: $1.5 \mathrm{~mL}$ of whole blood was collected in fluoride containing tube for blood glucose estimation. $1.5 \mathrm{~mL}$ was collected in sterile EDTA-containing tubes for assessment of CBC. The other part $(5 \mathrm{~mL})$ was left for 30 to 60 minutes for spontaneous clotting at room temperature before being centrifuged at 4000 rpm for 10 minutes. Serum samples were used for determination of lipid profile, viral markers, liver and kidney function tests, serum insulin, serum resistin. Serum samples were kept frozen at $-20^{\circ} \mathrm{C}$ for determination of resistin and insulin.

- Routine laboratory workup Included complete blood picture, liver function tests, Renal function tests, fasting lipid profile assay, Fasting and post prandial blood sugar and Viral markers, HBsAg and HCV Ab.

- Special testes

1- Serum Fasting Insulin levels: [8] Measured by ELISA (RayBio® Human Insulin ELISA Kit, Catalog \#: ELH-Insulin). A $50 \mathrm{uL}$ of 
Samples was added to the appropriate antibody pre-coated Microtiter Plate. $50 \mathrm{uL}$ of PBS ( $\mathrm{pH}$ 7.0-7.2) was added in the blank control well $100 \mathrm{uL}$ of Conjugate was added to each well (NOT blank control well) and mixed well. The plate was covered and incubated for 1 hour at $37^{\circ} \mathrm{C}$, then the microtiter plate was washed for 4 times. $50 \mathrm{uL}$ Substrate A and $50 \mathrm{uL}$ and substrate $\mathrm{B}$ were added to each well including blank control well, subsequently. The plate was covered and incubated for $10-15$ minutes at $20-25^{\circ}$ C. 50 $\mathrm{uL}$ of Stop Solution was added to each well including blank control well and mixed well. The Optical Density (O.D.) was determined at $450 \mathrm{~nm}$ using a microplate reader immediately. The normal fasting Insulin levels $<25 \mathrm{mIU} / \mathrm{L}$. Insulin resistance by homeostasis model assessment (HOMA-IR) was calculated by the following formula: (Fasting insulin $\mathrm{x}$ Fasting glucose/405). HOMA-IR below 3 indicates normal insulin resistance and Above 3 indicates significant insulin resistance.

2- Serum resistin level [9]: Serum values of resistin were measured by ELISA (Human Resistin Elisa kit, Catalog Number: MBS720386). A $100 \mu 1$ of each standard and sample was added into appropriate wells. Cover well and incubate for 2.5 hours at room temperature or overnight at $4^{\circ} \mathrm{C}$ with gentle shaking. The solution was discarded, and the plate was washed 4 times with $1 \mathrm{X}$ Wash Solution. $100 \mu \mathrm{l}$ of $1 \mathrm{X}$ prepared biotinylated antibody was added to each well. And the plate was incubated for 1 hour at room temperature with gentle shaking. The solution was discarded. The wash was repeated. $100 \mu 1$ of prepared Streptavidin solution was added to each well. The plate was incubated for 45 minutes at room temperature with gentle shaking. The solution was discarded. The wash was repeated. 100 $\mu 1$ of TMB One-step Substrate Reagent was added to each well. The plate was incubated for 30 minutes at room temperature in the dark with gentle shaking. 8. $50 \mu \mathrm{l}$ of Stop Solution was added to each well. The plate was read at $450 \mathrm{~nm}$ immediately.

- Imaging workup

Pelviabdominal ultrasound (Sonoscape S11).

For determining hepatic size, parenchyma echogenicity and brightness and exclusion of ascites and splenomegaly.

\section{U/S Grading of NAFLD [11]}

Grade I: Minimal diffuse increase in the fine echoes. Liver appears bright compared to the cortex of the kidney. Normal visualization of diaphragm and intrahepatic vessel borders.

Grade II: Moderate diffuse increase in the fine echoes. Slightly impaired visualization of the intrahepatic vessels and diaphragm.

Grade III: Marked increase in the fine echoes. Poor or no visualization of intrahepatic vessels and diaphragm and poor penetration of the posterior, segment of the right lobe of the liver.

- Liver biopsy Technique [10] Liver biopsy was done only for patient group using a semiautomatic true cut needle 16 gauge after taking informed consent and assessment of prothrombin time and platelet count. Patient was brought into the equipped room, he was asked to lay on his back with the right arm up behind his neck to expose the right side of the body. After marking of the skin, an antiseptic was applied, the patient was given an intravenous sedation. A local anesthetic like xylocaine was also used at the biopsy site. A small cut was made in the skin about $5 \mathrm{~mm}$ long to let the needle pass through more easily, where the biopsy needle was passed through to the liver and the sample was taken and was put in formalin for histopathological examination. Occasionally the biopsy was too small and in these cases, it was needed to pass the needle a second or a third time. The required time to stay in bed was four hours after the procedure. The patient was instructed to lay on this side immediately after the procedure and after one hour he can sit up slightly.

\section{Statistical analysis}

Data were checked, entered and analyzed using SPSS 22 for Windows (SPSS Inc., Chicago, IL, USA). Data were expressed as mean \pm SD for quantitative variable, number and percentage for qualitative one. Chi-squared $\left(\mathrm{X}^{2}\right)$ or $\mathrm{t}$ test and paired $t$ test were used when appropriate. $\mathrm{P}<0.05$ was considered significant. $\mathrm{P}<0.001$ was considered high significant.

\section{RESULTS}

BMI was significantly higher among NASH group when compared to control group. (Table 1). There was a significant difference as regard 
ALT \& AST in NASH group in comparison with control group. (Table2). There was a significant difference as regard triglycerides, total cholesterol, LDL \& HDL in NASH group in comparison with control group (Table 3). There was a significant difference as regard fasting blood glucose, post prandial blood glucose, insulin \& HOMA-IR in NASH group in comparison with control group (Table 4). There was a significant difference as regard serum resistin in NASH group in comparison with control group (Table 5). A positive correlation in NASH group between serum resistin and the following parameters: age, BMI, ALT, AST, TGs, Cholesterol, LDL, Fasting and postprandial blood glucose, insulin and HOMAIR (Table 6). Cutoff value of serum resistin was $>3.7 \mathrm{ng} / \mathrm{ml}$ (Table 7).

Table (1): Demographic data of the studied groups

\begin{tabular}{|c|c|c|c|c|c|}
\hline \multirow{2}{*}{ Demographic data } & \multicolumn{2}{|c|}{ Control group $(\mathrm{N}=19)$} & \multicolumn{2}{|c|}{$\begin{array}{c}\text { Patient group } \\
(N=19)\end{array}$} & \multirow[b]{2}{*}{$\mathbf{p}$} \\
\hline & N. & $\%$ & $\mathbf{N}$. & $\%$ & \\
\hline \multicolumn{6}{|l|}{ Sex } \\
\hline Male & 11 & $57.9 \%$ & 13 & $68.4 \%$ & \multirow[t]{2}{*}{0.501} \\
\hline Female & 8 & $42.1 \%$ & 6 & $31.6 \%$ & \\
\hline \multicolumn{6}{|l|}{$\overline{\text { Age (years) }}$} \\
\hline Mean \pm SD & \multicolumn{2}{|c|}{$43.26 \pm 6.81$} & \multicolumn{2}{|c|}{$44.05 \pm 5.45$} & \multirow[t]{2}{*}{0.696} \\
\hline Median (Range) & \multicolumn{2}{|c|}{$43(33-55)$} & \multicolumn{2}{|c|}{$45(35-53)$} & \\
\hline$<40$ years & 6 & $31.6 \%$ & 5 & $26.3 \%$ & \multirow[t]{3}{*}{0.809} \\
\hline $40-49$ years & 8 & $42.1 \%$ & 10 & $52.6 \%$ & \\
\hline$\geq 50$ years & 5 & $26.3 \%$ & 4 & $21.1 \%$ & \\
\hline \multicolumn{6}{|l|}{ BMI $\left(\mathrm{kg} / \mathrm{m}^{2}\right)$} \\
\hline Mean \pm SD & \multicolumn{2}{|c|}{$23.46 \pm 0.76$} & \multicolumn{2}{|c|}{$32.71 \pm 1.18$} & \multirow[t]{2}{*}{$<0.001$} \\
\hline Median (Range) & \multicolumn{2}{|c|}{$23.5(22.2-24.9)$} & \multicolumn{2}{|c|}{$32.70(30.6-34.8)$} & \\
\hline Average & 19 & $100 \%$ & 0 & $0 \%$ & \multirow[t]{2}{*}{$<0.001$} \\
\hline Overweight & 0 & $0 \%$ & 19 & $100 \%$ & \\
\hline
\end{tabular}

Table (2): Comparison between Control group \& patient group as regard liver function test

\begin{tabular}{|c|c|c|c|}
\hline Liver function tests & $\begin{array}{c}\text { Control group } \\
(N=19)\end{array}$ & $\begin{array}{c}\text { Patient group } \\
(N=19)\end{array}$ & $\mathbf{p}$ \\
\hline \multicolumn{4}{|l|}{ T. Protein (gm/dl) } \\
\hline Mean \pm SD & $7.35 \pm 0.66$ & $7.46 \pm 0.72$ & 0.649 \\
\hline \multicolumn{4}{|l|}{ Albumin (gm/dl) } \\
\hline Mean \pm SD & $4.97 \pm 0.77$ & $4.63 \pm 0.42$ & 0.122 \\
\hline \multicolumn{4}{|c|}{ Total serum bilirubin (mg/dl) } \\
\hline Mean \pm SD & $0.72 \pm 0.34$ & $0.86 \pm 0.39$ & 0.133 \\
\hline \multicolumn{4}{|c|}{ Direct serum bilirubin (mg/dl) } \\
\hline Mean \pm SD & $0.10 \pm 0.05$ & $0.11 \pm 0.04$ & 0.483 \\
\hline \multicolumn{4}{|l|}{ ALT (U/L) } \\
\hline Mean \pm SD & $25.63 \pm 7.58$ & $83 \pm 10.86$ & $<0.001$ \\
\hline \multicolumn{4}{|l|}{$\mathrm{AST}(\mathrm{U} / \mathrm{L})$} \\
\hline Mean \pm SD & $16.57 \pm 4.92$ & $56.68 \pm 7.33$ & $<0.001$ \\
\hline \multicolumn{4}{|l|}{ PT (sec.) } \\
\hline Mean \pm SD & $14.67 \pm 1.49$ & $15.49 \pm 1.64$ & 0.116 \\
\hline \multicolumn{4}{|l|}{ INR } \\
\hline Mean \pm SD & $0.97 \pm 0.08$ & $1.02 \pm 0.08$ & 0.123 \\
\hline
\end{tabular}


Table (3): Comparison between control group \& patient group as regard lipid profile

\begin{tabular}{|c|c|c|c|}
\hline Lipid profile & $\begin{array}{c}\text { Control group } \\
(\mathrm{N}=19)\end{array}$ & $\begin{array}{c}\text { Patient group } \\
(\mathrm{N}=19)\end{array}$ & p-value \\
\hline \multicolumn{4}{|l|}{ Triglycerides (mg/dl) } \\
\hline Mean \pm SD & $112.47 \pm 25.18$ & $249 \pm 63.37$ & \multirow[t]{2}{*}{$<0.001$} \\
\hline Median (Range) & $119(75-146)$ & $261(137-325)$ & \\
\hline \multicolumn{4}{|l|}{ T. Cholesterol (mg/dl) } \\
\hline Mean \pm SD & $181.89 \pm 11.13$ & $252.68 \pm 38.85$ & \multirow[t]{2}{*}{$<0.001$} \\
\hline Median (Range) & $185(164-199)$ & $260(179-304)$ & \\
\hline \multicolumn{4}{|l|}{ LDL (mg/dl) } \\
\hline Mean \pm SD & $103.63 \pm 12.10$ & $154.57 \pm 27.95$ & \multirow[t]{2}{*}{$<0.001$} \\
\hline Median (Range) & $100(87-124)$ & $157(105-200)$ & \\
\hline \multicolumn{4}{|l|}{$\underline{\mathrm{HDL}}(\mathrm{mg} / \mathrm{dl})$} \\
\hline$\overline{\text { Mean } \pm \text { SD }}$ & $55.89 \pm 8.24$ & $48.52 \pm 4.29$ & \multirow[t]{2}{*}{0.002} \\
\hline Median (Range) & $58(43-69)$ & $49(39-58)$ & \\
\hline
\end{tabular}

Table (4): Comparison between control group \&patient group as regard glucose metabolism

\begin{tabular}{|c|c|c|c|c|c|}
\hline \multirow{2}{*}{ Glucose metabolism } & \multicolumn{2}{|c|}{$\begin{array}{c}\text { Control group } \\
(N=19)\end{array}$} & \multicolumn{2}{|c|}{$\begin{array}{c}\text { Patient group } \\
(\mathrm{N}=19)\end{array}$} & \multirow[t]{2}{*}{ p-value } \\
\hline & N. & $\%$ & N. & $\%$ & \\
\hline \multicolumn{6}{|c|}{ Fasting blood glucose (mg/dl) } \\
\hline Mean \pm SD & \multicolumn{2}{|c|}{$78.94 \pm 9.02$} & \multicolumn{2}{|c|}{$104.78 \pm 22.69$} & $<0.001$ \\
\hline \multicolumn{6}{|c|}{ Postprandial blood glucose (mg/dl) } \\
\hline Mean \pm SD & \multicolumn{2}{|c|}{$121.05 \pm 7.30$} & \multicolumn{2}{|c|}{$160.63 \pm 55.74$} & 0.006 \\
\hline Normal & 19 & $100 \%$ & 9 & $47.4 \%$ & \multirow[t]{3}{*}{0.001} \\
\hline Prediabetes & 0 & $0 \%$ & 7 & $36.8 \%$ & \\
\hline Diabetes & 0 & $0 \%$ & 3 & $15.8 \%$ & \\
\hline \multicolumn{3}{|l|}{ Insulin ( $\mathrm{\mu IU} / \mathrm{mI})$} & \multirow{2}{*}{\multicolumn{2}{|c|}{$13.19 \pm 1.22$}} & \\
\hline Mean \pm SD & \multicolumn{2}{|c|}{$6.90 \pm 1.21$} & & & $<0.001$ \\
\hline \multicolumn{4}{|l|}{ HOMA-IR } & & \\
\hline$\overline{\text { Mean } \pm \text { SD }}$ & \multicolumn{2}{|c|}{$1.37 \pm 0.36$} & & 1.06 & \multirow[t]{2}{*}{$<0.001$} \\
\hline Median (Range) & \multicolumn{2}{|c|}{$1.40(0.70-2.00)$} & \multicolumn{2}{|c|}{$3.30(2.00-5.70)$} & \\
\hline Normal IR $(<3)$ & 19 & $100 \%$ & 6 & $31.6 \%$ & \multirow[t]{2}{*}{$<0.001$} \\
\hline Abnormal IR (>3) & 0 & $0 \%$ & 13 & $68.4 \%$ & \\
\hline
\end{tabular}

Table (5): Comparison between control group \& patient group as regard serum resistin $(\mathrm{ng} / \mathrm{ml})$

\begin{tabular}{|l|c|c|c|}
\hline \multicolumn{1}{|c|}{ Serum resistin (ng/ml) } & $\begin{array}{c}\text { Control group } \\
(\mathbf{N}=\mathbf{1 9})\end{array}$ & $\begin{array}{c}\text { Patient group } \\
(\mathbf{N}=\mathbf{1 9})\end{array}$ & p-value \\
\hline Mean \pm SD & $3.30 \pm 0.44$ & $5.58 \pm 0.94$ & $<0.001$ \\
\hline Median (Range) & $3.30(2.60-4.20)$ & $5.50(3.80-7.30)$ & $<$ \\
\hline
\end{tabular}


Table (6): Correlation between serum resistin $(\mathrm{ng} / \mathrm{ml})$ and other studied parameters in patient group $(\mathrm{N}=19)$

\begin{tabular}{|l|c|}
\hline & $\begin{array}{c}\text { Serum resistin }(\mathbf{n g} / \mathbf{m l}) \\
\text { p-value }\end{array}$ \\
\hline Age (years) & 0.004 \\
\hline BMI (kg/m2) & $<0.001$ \\
\hline Hemoglobin (gm/dl) & 0.421 \\
\hline WBCs (x103/mm3) & 0.403 \\
\hline Platelet count (x103/mm3) & 0.459 \\
\hline Protein (gm/dl) & 0.997 \\
\hline Albumin (gm/dl) & 0.283 \\
\hline Total serum bilirubin (mg/dl) & 0.318 \\
\hline Direct serum bilirubin (mg/dl) & 0.960 \\
\hline ALT (U/L) & 0.021 \\
\hline AST (U/L) & 0.018 \\
\hline PT (sec.) & 0.376 \\
\hline INR & 0.402 \\
\hline Creatinine (mg/dl) & 0.926 \\
\hline BUN (mg/dl) & 0.658 \\
\hline Triglycerides (mg/dl) & 0.001 \\
\hline Cholesterol (mg/dl) & 0.008 \\
\hline LDL (mg/dl) & 0.020 \\
\hline HDL (mg/dl) & 0.225 \\
\hline Fasting blood glucose (mg/dl) & $<0.001$ \\
\hline Postprandial blood glucose (mg/dl) & $<0.001$ \\
\hline Insulin ( $\boldsymbol{\mu I U / m l ) ~}$ & $<0.001$ \\
\hline HOMA-IR & $<0.001$ \\
\hline
\end{tabular}

Table (7): Validity of serum resistin as a diagnostic marker in Non- alcoholic steatohepatitis (NASH); ROC curve analysis

\begin{tabular}{|l|c|c|c|c|c|c|}
\hline \multicolumn{1}{|c|}{$\begin{array}{c}\text { CUT OFF } \\
\text { VALUES }\end{array}$} & $\begin{array}{c}\text { SN \% } \\
(\mathbf{9 5 \%} \mathbf{C I})\end{array}$ & $\begin{array}{c}\text { SP \% } \\
(\mathbf{9 5 \%} \text { CI })\end{array}$ & $\begin{array}{c}\text { PPV \% } \\
\mathbf{( 9 5 \%} \mathbf{C I})\end{array}$ & $\begin{array}{c}\text { NPV \% } \\
(\mathbf{9 5 \%} \text { CI })\end{array}$ & $\begin{array}{c}\text { ACCURACY } \\
(\mathbf{9 5 \%} \text { CI })\end{array}$ & $\begin{array}{c}\text { AUROC } \\
(\mathbf{9 5 \%} \% \mathbf{C I})\end{array}$ \\
\hline $\begin{array}{l}\text { Serum resistin } \\
\mathbf{3 . 7} \mathbf{~ n g} / \mathbf{m l}\end{array}$ & $100 \%$ & $89.4 \%$ & $90.5 \%$ & $100 \%$ & $94.7 \%$ & 0.989 \\
$(82.4-100)$ & $(66.9-98.7)$ & $(69.6-98.8)$ & $(80.5-100)$ & $(74.7-99.4)$ & $(0.887-1.000)$ \\
\hline
\end{tabular}

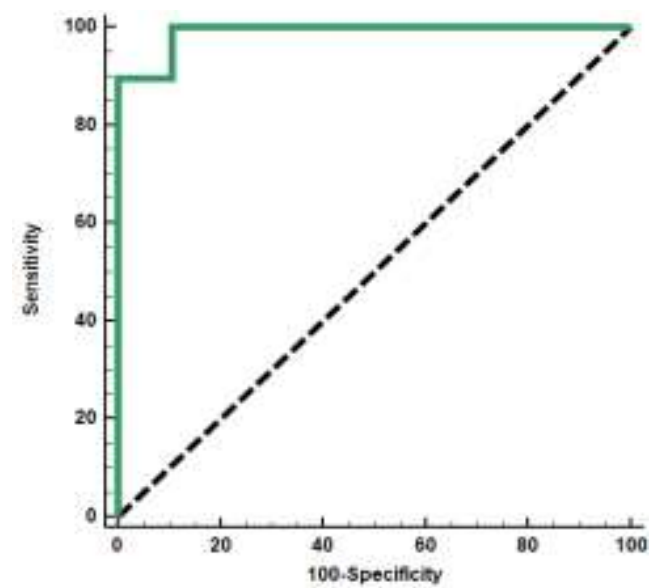

Figure (1): Receiver operating characteristic (ROC) curve of serum resistin as a diagnostic marker in Non- Alcoholic Steatohepatitis (NASH) 


\section{DISCUSSION}

NAFLD is one of the reasons of a fatty liver occurring when fat is deposited in the liver due to causes other than excessive alcohol use [2] while Non-Alcoholic steatohepatitis is a subgroup of NAFLD patients which characterized by damage to and inflammation of hepatocytes in addition to excessive fat steatohepatitis. NASH is practically indistinguishable histologically from alcoholic steatohepatitis and is characterized by fatty infiltration of the liver with different degrees of inflammation, necrosis, and fibrosis, almost identical to those of alcoholic liver disease [4]. Resistin is a polypeptide particularly emitted from adipocytes and its serum concentration rising is usually associated with obesity [3]. This study was aimed to determine the importance of resistin as a diagnostic marker for NASH.

Our participants age and sex were matched but a significant difference regarding BMI $\left(\mathrm{kg} / \mathrm{m}^{2}\right)$ was found between the two studied groups with mean $\pm \mathrm{SD}(23.46 \pm 0.76)$ in control group and mean \pm $\mathrm{SD}\left(32.71 \pm 1.18 \mathrm{~kg} / \mathrm{m}^{2}\right)$ in patient group.

We reported a significant difference in serum level of both ALT $(25.63 \pm 7.58 \mathrm{U} / \mathrm{L})$ and $(83 \pm$ $10.86 \mathrm{U} / \mathrm{L})$, and AST $(16.57 \pm 4.92 \mathrm{U} / \mathrm{L})$ and $(56.68 \pm 7.33 \mathrm{U} / \mathrm{L})$ in control group and patient group respectively. These results agree with those of Pagano et al. [12] who found significant difference between the NAFLD group, that was sub classified to pure fatty liver and NASH, and control group. Also, Shen et al. [13] reported the same finding, however, there was no significant difference between the two groups as regard total protein, albumin, total bilirubin, direct bilirubin, PT and INR in this study.

In our study, triglycerides showed a significant difference in comparison between the two groups the mean \pm SD of control group was (112.47 \pm $25.18 \mathrm{mg} / \mathrm{dl})$ and of patient group was $(249 \pm$ $63.37 \mathrm{mg} / \mathrm{dl}$ ), this comes in accordance with the results of Pagano et al. [12].

Serum cholesterol level $(\mathrm{mg} / \mathrm{dl})$ showed a significant difference $(181.89 \pm 11.13)$ and $(252.68 \pm 38.85)$ between control and NASH group respectively. Senates et al. [14] stated the same between NAFLD group (53\% patients had definite NASH) and control group, while Shen et al. [13] results showed no significant difference between control and NASH group, this discrepancy may be related to the difference in nutritional habits between the different compared societies and also partial to selection criteria of NASH patients who are on default have high BMI

Our study showed a significant difference between the control group and NASH group as regard serum LDL $(103.63 \pm 12.10 \mathrm{mg} / \mathrm{dl})$ and $(154.57 \pm$ $27.95 \mathrm{mg} / \mathrm{dl})$ receptively and HDL (55.89 \pm 8.24$)$ and $(48.52 \pm 4.29 \mathrm{mg} / \mathrm{dl})$ receptively. Our findings come in agreement with Senates et al. [14].

Fasting blood glucose $(\mathrm{mg} / \mathrm{dl})$ was found to be significantly different between the control and NASH group $(78.94 \pm 9.02)$ and $(104.78 \pm 22.69)$ respectively. Mohamed et al. [15] reported the same finding between the control and NAFLD group (which was further subclassified to NASH, border line NASH and not NASH), also they added that the fasting blood glucose increased more in NASH than in non-NASH with no significant difference in between them. However, Pagano et al. [12] results doesn't agree with our results, as diabetic patients were excluded in our study. Postprandial blood glucose $(\mathrm{mg} / \mathrm{dl})$ also was found to be significantly different between both control and NASH group (121.05 \pm 7.30$)$ and $(160.63 \pm 55.74)$ respectively. This go in accordance with the results of Mohamed et al. [15] who added that post prandial blood glucose increased more in NASH than in non-NASH but without significant difference in between them.

A significant different was found regarding mean \pm SD of serum Insulin $(\mu \mathrm{IU} / \mathrm{ml})$ in our study between the control group and NASH group $(6.90 \pm 1.21)$ and $(13.19 \pm 1.22)$ respectively. While the results reported by Pagano et al. [12] comparing the control with NASH group were $(7.8 \pm 0.8)$ and $(10.9 \pm 1.1)$ respectively.

HOMA-IR index that represent insulin resistant showed a significant difference in our study between the two groups where the control and NASH group $(1.37 \pm 0.36)$ and $(3.42 \pm 1.06)$ respectively. This finding comes parallel to those obtained by Pagano et al. [12].

Serum resistin $(\mathrm{ng} / \mathrm{ml})$ was found significantly elevated in NASH group in comparison to the control $(5.58 \pm 0.94)$ and $(3.30 \pm 0.44)$ respectively. Shen et al. [13] confirmed this result in his study comparing NAFLD group $(6.30 \pm 1.54 \mathrm{ng} / \mathrm{ml})$ to the control group $(3.14 \pm 1.22)$. Moreover, resistin level in NASH group was more than that of NAFLD group but with no significant difference in NAFLD subtypes. Mohamed et al., 2010 [15] also found a significant difference between the NAFLD group (16.2 \pm 4$)$ and control group (3.4 
\pm 1.1 ), but they reported no significant difference in NAFLD subtypes patients where NASH patients whose $(19.2 \pm 3.6)$ had higher resistin than non-NASH patients whose mean \pm SD $(13.5$ $\pm 2.7 \mathrm{ng} / \mathrm{ml}$ ) with a significant difference between them. Also, Pagano et al. [12] results is compatible with Mohamed et al. [15] where the comparison between NAFLD group $(5.87 \pm 0.49 \mathrm{ng} / \mathrm{ml})$ and control group $(4.30 \pm 0.20 \mathrm{ng} / \mathrm{ml})$ showed a significant difference, and they also said that in steatohepatitis patients significant higher resistin levels were found compared with those of pure fatty liver. Senates et al. [14] also reported a similar result near to our study.

We reported also a positive correlation between serum resistin and BMI. Our result was supported by results obtained by Lu et al. [16] While, Jiang et al. [17] didn't found any positive correlation. This contradiction may be related to selection criteria for the included participants.

A positive correlation was found in our study between serum resistin and patient age. This may be attributable to aging process with increase in fat content as reported by Oliver et al. [18] while, Pagano et al. [12] reported the opposite to our results and stated that there was no any positive correlation between age and serum resistin in NASH patients, this may be related to patients selection where the BMI $\left(\mathrm{kg} / \mathrm{m}^{2}\right)$ of our study was $(32.71 \pm 1.18)$ while those of Pagano et al., 2006 [12] was $(27.3 \pm 0.6)$.

A positive correlation also was found in our study in NASH group between serum resistin and serum ALT and AST, serum triglycerides, serum cholesterol and serum LDL. This was reported and confirmed by Mohamed et al. [15].

The positive correlation that was reported in our study in NASH patients between serum resistin, and both fasting and postprandial blood glucose were supported and enforced by results obtained by both Lu et al. [16] however, Pagano et al. [12] reported no significant correlation, may be related to his inclusion and exclusion criteria as he excluded previously diagnosed diabetic patients, according to the American Diabetes Association classification.

A high positive correlation was found in our study between serum resistin, serum insulin and HOMA IR. These agree with Both Mohamed et al. [15] and Senates et al. [14].

\section{CONCLUSION}

- Serum resistin level is higher among NASH group. At cut off value $>3.7 \mathrm{ng} / \mathrm{ml}$

- Serum resistin level is a good diagnostic marker for NASH.

Funding: None.

Conflicts of interest: None.

Ethical approval:Approved and informed consents were obtained from all patients.

\section{REFERENCES}

1. Reddy JK, Rao MS. Lipid metabolism and liver inflammation. II. Fatty liver disease and fatty acid oxidation. Am. J. Physiol. Gastrointest. Liver Physiol. 2006, 290 (5): G852-8.

2. Shaker M, Tabbaa A, Albeldawi M, Alkhouri N. Liver transplantation for nonalcoholic fatty liver disease: new challenges and new opportunities. World J Gastroenterol.; 2014, 20(18): 5320-30.

3. Stojsavljević S, Gomerčić Palčić M, Gomerčić Palčić L, Smirčić Duvnjak L, Duvnjak M, Adipokines and proinflammatory cytokines, the key mediators in the pathogenesis of nonalcoholic fatty liver disease. World J Gastroenterol.; 2014, 20(48): 18070-91.

4. Cheung O, Sanyal AJ. Recent advances in nonalcoholic fatty liver disease. Curr Opin Gastroenterol. May; 2010, 26(3):202-8.

5. Angulo P. Nonalcoholic Fatty Liver Disease $N$ Engl J Med 2002, 346:1221-1231.

6. Osawa H, Onuma H, Murakami A, Ochi M, Nishimiya T, Kato K, et al. Systematic search for single nucleotide polymorphisms in the resistin gene: the absence of evidence for the association of three identified single nucleotide polymorphisms with Japanese type 2 diabetes. Diabetes; 2002, 51(3): 863-6.

7. Ronti T, Lupattelli G, Mannarino E. The Endocrine Function of Adipose Tissue: An Update. Clin Endocrinol.; 2006, 64(4): 355-65.

8. Monteiro PA, Mota J, Silveira LS, Cayres SU, Antunes BM, Fernandes RA, et al. Morphological and metabolic determinants of nonalcoholic fatty liver disease in obese youth: a pilot study. $B M C$ Res Notes; 2013, 6:89.

9. Clark HF, Gurney AL, Abaya E, Baker K, Baldwin D, Brush J, et al. The Secreted Protein Discovery Initiative (SPDI), a Large-Scale Effort to Identify Novel Human Secreted and Transmembrane Proteins: A Bioinformatics Assessment. Genome Res. Oct; 2003, 13(10): 2265-2270. 
10. Copel L1, Sosna J, Kruskal JB, Kane RA. Ultrasoundguided percutaneous liver biopsy: indications, risks, and technique. Surg Technol Int.; 2003, 11:154-60

11. Mahaling DU, Basavaraj MM, Bika AJ. Comparison of lipid profile in different grades of non-alcoholic fatty liver disease diagnosed on ultrasound. Asian Pac J Trop Biomed; 2013, 3(11): 907-912.

12. Pagano C, Soardo G, Pilon C, Milocco C, Basan $\mathrm{L}$, Milan $\mathrm{G}$, et al. Increased serum resistin in nonalcoholic fatty liver disease is related to liver disease severity and not to insulin resistance. $J$ Clin Endocrinol Metab; 2006, 91: 1081-1086

13. Shen C, Zhao C, Wang W, Wang YD, Sun H, Cao $\mathrm{W}$, et al. The relationship between hepatic resistin overexpression and inflammation in patients with nonalcoholic steatohepatitis. BMC Gastroenterol.; 2014, 14: 39 .

14. Senates E, Çolak Y, Yesil A, Coşkunpinar E, Sahin O, Kahraman OT, et al. Circulating resistin is elevated in patients with non-alcoholic fatty liver disease and is associated with steatosis, portal inflammation, insulin resistance and nonalcoholic steatohepatitis scores. Minerva Med; 2012, 103:1-2.

15. Mohamed AS, Elsayed ES, Abd Elal H, HewedilH. Diagnostic Role of Resistin In Nonalchoholic Fatty Liver Disease. Report and Opinion; 2010, 2(11).

16. Lu H, Wang H, Wen Y, Zhang M, Lin H. Roles of adipocyte derived hormone adiponectin and resistin in insulin resistance of type 2 diabetes. World J Gastroenterol March 21; 2006, 12(11): 1747-1751.

17. Jiang LL, Li L, Hong XF, Li YM, Zhang BL. Patients with nonalcoholic fatty liver disease display increased serum resistin levels and decreased adiponectin levels. Eur J Gastroenterol Hepatol; 2009, 21:662-666.

18. Oliver P, Pico C, Serra F, Palou A. Resistin expression in different adipose tissue depots during rat development. Mol. Cell Biochem., 2003, 252: 397-400. 